\title{
LIABILITY OF SHIPPERS FOR ACCEPTING REBATES UNDER THE SHIPPING ACT OF 1916
}

The Shipping Act of $1916^{1}$ provides that a common carrier engaged in international shipping can be fined ${ }^{2}$ for granting a rebate of a portion of the applicable charge under the rate schedule filed by the carrier as required by the Act. ${ }^{3}$ The question of whether a shipper ${ }^{4}$ will be similarly liable for accepting such a rebate, however, has not yet been fully resolved. The statute is ambiguous in that the two provisions dealing specifically with rebates are addressed to carriers only, while the section prohibiting rate discrimination by shippers makes no explicit reference to rebates. ${ }^{5}$

The Federal Maritime Commission (FMC) has recently initiated a policy of strict enforcement with regard to the granting and accepting of rebates in international shipping. In 1976, the FMC began an investigation into what was thought to be a widespread practice by carriers of paying illegal rebates on their cargo rates. ${ }^{6}$ According to a Commission spokesman, rebating intensifies when the domestic economy of the United States is

1. 46 U.S.C. $\$ \$ 801-842$ (1970 \& Supp. V 1975).

2. See 46 U.S.C. $\$ \S 812,817(\mathrm{~b})(3)$ (1970). These provisions of the Shipping Act contain explicit statements of the carrier's liability for granting a rebate. See notes 36-40 infra and accompanying text. See, e.g., United States v. Pan Am. Mail Line, Inc., 359 F. Supp. 728 (S.D.N.Y. 1972); Federal Maritime Comm'n v. Maersk Line, 243 F. Supp. 561 (S.D.N.Y. 1965).

3. 46 U.S.C. $\$ 817$ (b)(1) (1970). See notes $30-32$ infra and accompanying text.

4. The term "shipper" is not expressly defined in the Shipping Act, but it is "commonly understood to mean the owner or person for whose account the carriage of the goods is undertaken." Norman G. Jensen, Inc. v. Federal Maritime Comm'n, 497 F.2d 1053, 1056 (8th Cir. 1974); accord, Compagnie Général Transatlantique v. American Tobacco Co., 31 F.2d 663, 667 (2d Cir.), cert. denied, 280 U.S. 555 (1929). In most instances, the beneficial interest will be owned by the legal title holder, but it may be granted to another, either by agreement or by operation of law. 497 F.2d at 1057. See Note, The Bases and Range of Federal Maritime Law: Indicia of Maritime Competence, 6 VAND. J. TRANSNAT'L L. 187, 217 (1972). See notes 42-48 infra and accompanying text for a discussion of the significance of the omission from the statute of the definition of this term.

5. Section $18(b)(3), 46$ U.S.C. $\& 817(b)(3)$ (1970), prohibits any carrier from granting a rebate. Carriers are forbidden to pay deferred rebates to any shipper by $\S 14, i d$. $\S 812$. Both provisions are addressed to carriers only. Discriminatory acts by a shipper are prohibited by $\S$ 16,46 U.S.C. $\$ 815$ (1970 \& Supp. V 1975). However, that provision merely prohibits the use of any unjust or unfair device to obtain transportation at less than the rates otherwise applicable. The statutory language does not expressly include the receipt of rebates by shippers within the scope of the proscribed activity. See notes 36-40, 49 infra and accompanying text.

6. Ocean Carriers Studied by Maritime Agency for Possible Kickbacks, Wall St. J., July 19,1976 , at 3 , col. 5 . 
strong in relation to relatively stagnant foreign economies. ${ }^{7}$ Since a strong domestic economy results in a decrease in foreign demand for American goods, carriers may be forced to travel overseas without full loads. In order to increase cargo loads, carriers sometimes offer customers kickbacks "under the table" or for deposit in foreign banks. ${ }^{8}$ One shipper voluntarily disclosed to the FMC that it had received rebates from various carriers in order to determine whether the acceptance of rebates constituted a violation of the Shipping Act giving rise to civil liability. ${ }^{9}$ However, in that case the corporation involved ceased its practice of accepting rebates voluntarily, rather than in response to an enforcement action by the FMC. ${ }^{10}$

\section{GRANTING AND ACCEPTING OF REBATES IN THE FIELD OF INTERNATIONAL SHIPPING}

In January, 1977, Sea-Land Service, a subsidiary of R.J. Reynolds Industries, Inc., agreed to pay a $\$ 4$ million civil penalty in a settlement with the FMC of charges involving illegal rebates to shippers, the largest settlement reached in the history of any transportation regulatory agency. ${ }^{11}$ In addition to the monetary penalty, Sea-Land agreed to pay the government all of the proceeds it received from rebates and to set up new procedures to prevent such violations from recurring. ${ }^{12}$

At the time the Sea-Land settlement was announced, the Commission indicated that enforcement actions against other carriers and shippers were planned. ${ }^{13}$ Several months later, a $\$ 340,000$ civil penalty was paid by Sony Corp. and its U.S. subsidiary in settlement of FMC charges that Sony had received kickbacks from carriers. ${ }^{14}$ The FMC plans to institute further enforcement actions against both foreign and domestic shippers and carriers suspected of participating in illegal rebating schemes. ${ }^{15}$ The Commission is currently investigating approximately eighteen foreign-flag carriers for pos-

7. Id.

8. Id.

9. Action Industries Discloses Rebates from Sea Carriers, Wall St. J., Oct. 11, 1976, at 8, col. 2. It was revealed that a Hong Kong subsidiary of Action Industries had accepted approximately $\$ 390,000$ in cash from carriers as rebates on freight charges. Id.

10. Id.

11. R.J. Reynolds Unit Settles for \$4 Million in U.S. Rebate Case, Wall St. J., Jan. 6, 1977, at 6 , col. 2 .

12. Id. A decision by the Justice Department on the question of whether to prosecute SeaLand for conspiracy to violate the Shipping Act is now pending. More Ship Rebate Hearings Are Urged, J. Com., Jan. 26, 1978, at 1, col. 7 at 3, col. 8. See note 17 infra and accompanying text.

13. More Ship Rebate Hearings Are Urged, supra note 12.

14. Sony, U.S. Unit Settle with Federal Agency on Alleged Kickbacks, Wall St. J., Aug. 22, 1977, at 3, col. 3; Settlement Agreement Between Sony Corp. and Its Affiliate Sony Corp. of America and the Federal Maritime Commission (August 18, 1977) (copy on file with the Duke Law Journal).

15. R.J. Reynolds Unit Settles for \$4 Million in U.S. Rebate Case, supra note 11, at 6, col. 2. 
sible rebating violations. ${ }^{16}$ In addition, the FMC has referred charges of extensive illegal rebating by a foreign carrier to the Justice Department for the institution of either civil or criminal proceedings. ${ }^{17}$

、 In addition to its stepped-up enforcement efforts, the FMC may soon be equipped with more powerful enforcement tools. The House Merchant Marine and Fisheries subcommittee is presently engaged in efforts to draft new legislation that would impose more stringent sanctions upon shippers and carriers involved in rebating in the foreign trades. ${ }^{18}$ The pending bill ${ }^{19}$ would empower the FMC to close United States ports to carriers defying commission orders and would grant a limited form of amnesty or immunity from prosecution to those carriers or shippers who volunteer information with respect to illegal rebates and other Shipping Act offenses. ${ }^{20}$

Thus far, the companies that have been subject to FMC investigations have opted to pay their fines rather than resort to litigation. ${ }^{21}$ Yet, when the matter is eventually litigated, it is not at all certain that the Commission's position favoring the liability under the Shipping Act of a shipper who accepts a rebate will prevail. Persuasive arguments have been made in opposition to such a construction of the statute ${ }^{22}$ and these arguments are

16. Sea-Land Rebating: To Prosecute or Not, J. Com., Jan. 25, 1978, at 1, col 4, at 17, col. 7. The FMC' believes that foreign governments are shielding records of transactions involving illegal rebating by foreign shipping lines. R.J. Reynolds Unit Settles for \$4 Million in U.S. Rebate Case, supra note 11, at 6, col. 2.

17. Justice Unit To Weigh Alleged Illegal Rebates by Atlantica Ship Line, Wall St. J., June 1,1977 , at 4, col. 4 .

The Justice Department may be asked to prosecute carriers for conspiring to violate the anti-rebating statute. Conspiracy to commit an offense against the United States is expressly forbidden by statute. 18 U.S.C. $\$ 371$ (1970). Richard Bank, the director of the State Department's Office of Maritime Affairs, has refused to give any assurance to foreign governments that their carriers will not face criminal prosecution in the United States even if they comply with FMC orders. Sea-Land Rebating: To Prosecute or Not, supra note 16 at 17, col. 7. However, it should be noted that there have been no prosecutions of parties for conspiracy to violate the Shipping Act by the Justice Department since 1972. Id.

There is some question as to whether the Jústice Department has jurisdiction to prosecute for conspiracy in view of the fact that the rebating provisions of the Shipping Act carry onlv civil penalties, 46 U.S.C. $\$ 815$ (Supp. V 1975); 46 U.S.C. $\$ 817(b)(3)$ (1970), and the matter is supposed to be within the exclusive jurisdiction of the FMC. More Ship Rebate Hearings Are Unged, supra note 12, at 1, col. 1, at 7, col. 7. (position of Rep. Paul N. McCloskey, R. Calif., House Merchant Marine and Fisheries Subcommittee member).

18. Sea-Land Rebating: To Prosecute or Not, supra note 16, at 1, col. 4, at 17, col. 7.

19. H.R. 9518, 95th Cong., 1st Sess., 123 CoNG. REc. H10877 (daily ed. Oct. 12, 1977).

20. More Ship Rebate Hearings Are Urged, supra note 12, at 1 , col. 8 . In view of the proposed amnesty provision, companies have recently become reluctant to come forward with information regarding illegal granting and receipt of rebates. There have been no further voluntary admissions since early in 1977 when Sea-Land agreed to pay its settlement. SeaLand Rebating: To Prosecute or Not, supra note 16, at 1, col. 5.

21. See notes 13-16 supra and accompanying text.

22. See United States v. Peninsular \& Occidental S.S. Co., 208 F. Supp. 957, 958 (S.D.N.Y. 1962) (restricting shipper liability for accepting rebates to cases where there was an 
supported by the lack of any explicit provision for shipper rebate liability. However, the FMC's position would appear to be the most equitable, as well as the construction most consistent with the perceived congressional intent underlying the enactment of the Shipping Act. ${ }^{23}$

This Note will examine the legislative history and judicial opinions interpreting the applicable provisions of the statute in an attempt to resolve the ambiguity inherent in the statutory language. The possible resolution of the matter by the FMC through the use of its power to issue rules and regulations will also be considered. Finally, in view of the close parallel between the Shipping Act and the Interstate Commerce Act, analogous provisions of the latter statute also will be examined. The conclusion reached is that in order for the Shipping Act's goal of uniformity of treatment for all shippers and carriers to be realized, shippers must be held strictly liable for accepting rate rebates.

\section{AmbigutTy IN THE APPLICABle PROVISiONS OF THE SHIPPING ACT OF 1916}

The Constitution grants to Congress the power "to regulate Commerce with foreign Nations, and among the several States." 24 It was pursuant to this authority that Congress enacted the Shipping Act of $1916 .{ }^{25}$ The Shipping Act is a pervasive regulatory scheme, vesting in the FMC an extremely broad range of regulatory powers, particularly with regard to shipping in foreign commerce. ${ }^{26}$ The primary purpose of the Act is to achieve uniformity of treatment among both carriers and shippers. ${ }^{27}$ Conse-

attempt to conceal the rebate). See notes 61-63 infra and accompanying text. However, the validity of such a restriction is open to question. See notes 61-69 infra and accompanying text.

Although one court expressed doubt as to whether the Shipping Act was applicable to shippers under any circumstances, such-a conclusion has now been refuted. See notes 47-48 infra and accompanying text.

23. See notes 55-57 infra and accompanying text.

24. U.S. Const. art. I, § 8, cl. 3 .

25. Pub. L. No. $64-260,39$ Stat. 728 (1916). The constitutional basis is alluded to in H.R. ReP. No. 659, 64th Cong., 1st Sess. 33 (1916). See also Compagnie Générale Transatlantique v. American Tobacco Co., 31 F.2d 663, 665 (2d Cir.), cert. denied, 280 U.S. 555 (1929).

26. Carnation Co. v. Pacific Westbound Conf., 336 F.2d 650, 658 (9th Cir. 1964), rev'd on other grounds, 383 U.S. 213 (1966). Included within the broad scope of the Shipping Act's regulatory scheme are specific provisions dealing with deferred rebates and retaliation or discrimination against any shipper. 336 F.2d at 658.

27. 336 F.2d at 662 . The Senate Report states that "water carriers should be required to charge equal rates to all shippers irrespective of the volume of freight offered for shipment." $S$. REP. No. 689, 64th Cong., Ist Sess. 10 (1916). One court has interpreted the legislative history as follows:

The hearings and the Committee reports show that Congress was concerned both with protection of carriers against unscrupulous shippers, and of honest shippers against unscrupulous competitors, acting independently, or in collusion with a carrier.

We conclude that, while Section 16 covers the situation where the carrier is deceived or defrauded, it is not so limited. 
quently, the statute contains numerous provisions intended to limit competition $^{28}$ by preventing rate discrimination. ${ }^{29}$

The Shipping Act requires that common carriers by water engaged in foreign commerce file tariffs with the FMC setting forth the one and only rate to be charged and collected for transportation services on all established routes. These records are to be kept open for public inspection. ${ }^{30}$ Once the tariff has been properly filed with the FMC by the carrier, the public is deemed to have received constructive notice of all its terms and of all applicable requirements imposed by the Shipping Act; ${ }^{31}$ the tariff is then binding upon both the carrier and the shipper with the force of law. ${ }^{32} \mathrm{~A}$

Hohenberg Bros. Co. v. Federal Maritime Comm'n, 316 F.2d 381, 384-85 (D.C. Cir. 1963). Therefore, a shipper may challenge a carrier's rates as being unreasonably high and contrary to the public interest, while a competing carrier may challenge the rates as unreasonably low. The distinction is of no consequence, because the Shipping Act of 1916 and the 1961 amendments were designed to benefit both shippers and carriers. Federal Maritime Comm'n v. DeSmedt, 366 F.2d 464, 468 (2d Cir.), cert. denied, 385 U.S. 974 (1966).

28. Carnation Co. v. Pacific Westbound Conf., 336 F.2d 650, 660 (9th Cir. 1964), rev'd on other grounds, 383 U.S. 213 (1966). The purposes underlying the enactment of the Shipping Act may be contrasted with those leading to the passage of the antitrust acts.

[T] different from the objectives designed to be obtained through the antitrust acts. In the case of the latter, the congressional purpose was, as has been so often noted, to preserve, protect and enforce full and free competition. But the legislative history of the Shipping Act discloses that Congress had in mind in that enactment a very different objective due to the special problems of shipping lines in foreign trade which called for a special and different mode of regulation than that provided by the antitrust laws.

The Alexander Report which led to the enactment of the Shipping Act, discloses that the object of the Act was to permit a controlled system of agreements designed to limit competition.

336 F.2d at 660 (emphasis in original).

29. See, e.g., 46 U.S.C. $\S \S 812,813 \mathrm{a}, 815,816,833 \mathrm{a}$ (1970). The statute's prohibitions against discrimination may not be avoided through the use of individual contracts between carriers and shippers. The power of Congress to regulate is said to include the right to control the contract power of the carrier, to the extent that the public interest requires such limitation. Thus, the provisions of the statute are read into the contract and become a part of it. Shippers retain their freedom to contract with the carrier, but they are subject to the statutory rule that prohibits discrimination. Compagnie Générale Transatlantique v. American Tobacco Co., 31 F.2d 663, 666 (2d Cir.), cert. denied, 280 U.S. 555 (1929).

30. 46 U.S.C. $\$ 817(b)(1)(1970)$. This provision was enacted by Congress in 1961 as an extension of the filing requirement. Prior to that time, the statute merely required that common carriers by water in interstate commerce establish, observe and enforce just and reasonable rates. This requirement is still in effect. Maximum rates, fares and charges are to be filed with the FMC and kept open to public inspection. Id. $\$ 817($ a). See also United States v. Stephen Bros. Line, 384 F.2d 118 (5th Cir. 1967). There is also a requirement that common carriers by water file copies of all agreements with other such carriers that regulate transportation rates or provide for special rates, privileges, or advantages, including any exclusive, preferential or cooperative working arrangement. 46 U.S.C. § 814 (1970).

31. United States v. Central Gulf S.S. Corp., 340 F. Supp. 473, 478 (E.D. La. 1972), vacated and remanded on other grounds, 517 F.2d 687 (5th Cir. 1975).

32. Gilbert Imported Hardwoods, Inc. v. 245 Packages of Guatambu Squares, More or Less, 508 F.2d 1116, 1120-21 (5th Cir. 1975). However, it has been noted that it is not the establishment, publication or filing of an unlawful or unreasonable tariff that will afford 
policy of strict enforcement has been applied to the federally approved tariffs, and the specified rate must be charged and paid even in cases of mistake and without regard to a contrary intention by the parties involved..$^{33}$ The courts have recognized that such a strict interpretation may have quite harsh results, and may even require decisions contrary to well established principles of equity. However, the strict interpretation is considered essential "in order to effectuate the congressional scheme against rebating and collusive pricing." 34 It is believed that permitting exceptions to the rates established by tariff would constitute an open invitation to rebates and other unfair practices. ${ }^{35}$

Section 18(b)(3) of the Shipping Act provides:

No common carrier by water in foreign commerce or conference of such carriers shall charge or demand or collect or receive a greater or less or different compensation for the transportation of property or for any service in connection therewith than the rates and charges which are specified in its tariffs on file with the Commission and duly published and in effect at the time; nor shall any carrier rebate, refund or remit in any manner or by any device any portion of the rates or charges so specified, nor extend or deny to any person any privilege or facility, except in accordance with such tariffs. ${ }^{36}$

A civil penalty of up to $\$ 1,000$ for each day the violation continues is imposed upon "whoever" shall violate this provision. ${ }^{37}$ Although the language indicates that the penalty is theoretically applicable to any person committing a violation, the wording of the substantive offense, which refers only to carriers, makes it clear that shippers will not be subject to such a fine.

Another provision of the Shipping Act which deals specifically with rebates is section 14. Under that section, common carriers are forbidden to

grounds for affirmative relief, but only the attempted enforcement of such a tariff. Port of Bandon v. Oliver J. Olson \& Co., 175 F. Supp. 736, 742 (D. Ore. 1959).

33. Gilbert Imported Hardwoods, Inc. v. 245 Packages of Guatambu Squares, More or Less, 508 F.2d 1116, 1120-21 (5th Cir. 1975).

34. United States v. Pan Am. Mail Line, Inc., 359 F. Supp. 728, 733 (S.D.N.Y. 1972).

35. Id. at 736. However, the statutory purpose in imposing an obligation upon the carrier to collect the full freight was to eliminate price discrimination by the carrier and not to create an absolute liability on the part of the shipper. Therefore, in a case in which the shipper paid the full amount to a freight forwarder but the forwarder went bankrupt and consequently failed to pay the carrier, it was held that the statute had been satisfied and the public interest protected so long as any person was liable for the full amount of the freight. Farrell Lines, Inc. v. Titan Indus. Corp., 306 F. Supp. 1348, 1349 (S.D.N.Y.) aff'd per curiam, 419 F.2d 835 (2d Cir. 1969), cert. denied, 397 U.S. $1042(1970)$.

36. 46 U.S.C. $\S 817(b)(3)$ (1970) (emphasis added). However, the FMC is authorized to exercise its discretion to permit a carrier to refund a portion of the charges collected from a shipper or to waive the collection of a portion of the charges in the event of a clerical or administrative error, so long as no discrimination among shippers will result. Id.

37. 46 U.S.C. $\S 817(b)(6)$ (1970 \& Supp. V 1975). 
pay or allow, directly or indirectly, a deferred rebate ${ }^{38}$ to any shipper with regard to transportation of passengers or property by water between two United States ports, or between a United States and a foreign port. ${ }^{39}$ Any carrier violating this section is guilty of a misdemeanor, and may be subject to a fine of up to $\$ 25,000$ for each offense. ${ }^{40}$ Again, however, the punishment is, by its terms, specifically applicable to carriers only.

Thus, it would appear that the two provisions of the Shipping Act addressed specifically to rebates are not applicable to shippers accepting such rebates. These two sections of the statute deal merely with the civil or criminal liability of a common carrier who grants or pays a rebate to a shipper. It could be argued that, by not including a provision in the statute prohibiting shippers from accepting rebates and by failing expressly to mention the matter in the legislative history, Congress evidenced an intent to exempt shippers from liability. On the other hand, it is conceivable that the Congress simply felt that if rebates were eliminated as a lawful alternative, powerful shippers controlling a large volume of cargo would be deprived of any coercive influence that might enable them to demand rebate clauses in their transportation contracts with carriers. In the event of a violation of the rebate prohibition, it may have been believed that the shipper's liability was adequately provided for in other sections of the Shipping Act. ${ }^{41}$

It should be noted that the opening section of the Shipping $\mathrm{Act}^{42}$ is devoted to a listing of definitions of terms to be used in the interpretation of the remainder of the statute. The drafters were careful to include statutory definitions of such crucial terms as "common carrier by water," "common carrier by water in foreign commerce," and "common carrier by water in interstate commerce." 43 However, at no point is the term "shipper" either explained or defined. ${ }^{44}$ This omission has prompted courts to rely on the

38. The term "deferred rebate" is defined as

a return of any portion of the freight money by a carrier to any shipper as a consideration for the giving of all or any portion of its shipments to the same or any other carrier, or for any other purpose, the payment of which is deferred beyond the completion of the service for which it is paid, and is made only if, during both the period for which computed and the period of deferment, the shipper has complied with the terms of the rebate agreement or arrangement.

46 U.S.C. $\$ 812$ (1970).

39. Id.

40. Id.

41. See notes 49-81 infra and accompanying text.

42. 46 U.S.C. $\$ 801$ (1970).

43. The term "common carrier by water" is said to include both common carriers by water in foreign commerce and those in interstate commerce. Common carriers by water in foreign commerce are those engaged in the transportation by water of passengers or property between the United States and a foreign country, in either the import or export trade. A common carrier by water in interstate commerce is one engaged in such transportation on the high seas or the Great Lakes on regular routes between two United States ports. Id.

44. In addition, shippers are not included within the definition of the term "other person subject to this chapter," which is said to encompass those in the business of forwarding or 
accepted common law meaning in considering whether a particular party may be properly classified as a shipper ${ }^{45}$ Arguably, the failure to include "shipper" within the list of defined terms might serve as a general indication that the sanctions of the Shipping Act were not intended to apply to shippers. But such an argument is far from conclusive, and it might be asserted with equal force that the drafters simply considered the common law definition to be adequate. Support for the latter theory is found in the fact that the courts have also found it necessary to rely on the common law test in defining "common carrier," 46 although that term is certainly one of great significance in the application of the Act as a whole. Nonetheless, in view of the lack of any express prohibition directed toward shippers, one court has stated that it is doubtful whether shippers were intended to be subject to the Shipping Act at all. ${ }^{47}$ However, that opinion was written prior to the enactment of provisions dealing explicitly with violations by shippers ${ }^{48}$ and has thus been refuted as a general proposition.

In the entire Shipping Act, there is only one provision which, rather than simply holding the carrier responsible, imposes liability upon a shipper who obtains transportation for property at less than the filed tariff rate. Discriminatory acts by a shipper are prohibited by section 16 , which states:

It shall be unlawful for any shipper, . . . or any officer, agent, or employee thereof, knowingly and willfully, directly or indirectly, by means of false billing, false classification, false weighing, false report of weight, or by any other unjust or unfair device or means to obtain or attempt to obtain transportation by water for property at less than the rates or charges which would otherwise be applicable..$^{49}$

Any violation of this provision is deemed to be a civil offense carrying a penalty of as much as $\$ 5,000$ for each violation. ${ }^{50}$ Thus, the statute clearly does contemplate that shippers may be sanctioned for behaving in a way that is detrimental to the objectives sought to be achieved through the statute..$^{51}$

furnishing warehouse or other similar terminal facilities in connection with a common carrier by water. Id.

45. See, e.g. , Jensen v. Federal Maritime Comm'n, 497 F.2d 1053, 1056 (8th Cir. 1974). See note 4 supra.

46. See, e.g., Grace Line, Inc. v. Federal Maritime Bd., 280 F.2d 790, 792 (2d Cir. 1960), cert. denied, 364 U.S. 933 (1961). In that case, the court accepted the common law test which regarded a carrier as a "common carrier" only when it held itself out as such. 280 F.2d at 792.

47. Prince Line, Ltd. v. American Paper Exports, Inc., 55 F.2d 1053, 1056 (2d Cir. 1932) (dicta).

48. See, e.g. 46 U.S.C. $\S 815$ (1970 \& Supp. V 1975).

49. 46 U.S.C. \& 815 (1970 \& Supp. V 1975) (emphasis added). Common carriers are also prohibited from allowing any person to obtain transportation for less than the regular rates by such unfair devices or means. 46 U.S.C. $\$ 815$ (Second) (1970).

50. 46 U.S.C. \& 815 (Supp. V 1975).

51. The Federal Maritime Commission quoted the following statement by Congress as indicative of the purpose underlying the enactment of $\S 16$ of the Shipping Act: 
The question that must be resolved is whether the acceptance of a rebate may be seen to constitute a means or device for obtaining transportation at a lower rate than the published tariff, in contravention of section 16. In Hohenberg Brothers v. Federal Maritime Commission, ${ }^{52}$ the court held that since a rebate granted on the basis of false claims is similar in nature to a "false billing" or a "false classification," 53 such a rebate would constitute an "unjust or unfair device or means" within the scope of section $16 .{ }^{54}$ But not every rebate will be similar in nature to one of the specific offenses enumerated in the statute. In order to hold the shipper liable in those cases, it will be necessary to determine that the general proscription against the use of any unfair device or means for obtaining transportation at less than the lawful rate prohibits the acceptance of any rebate.

Logic would indicate that a rebate certainly should qualify as such an unlawful device. As noted above, the tariff, once filed, is said to bind both the carrier and the shipper with the force of law. ${ }^{55}$ Furthermore, the carrier is expressly prohibited from granting any rebates to shippers. ${ }^{56}$ It is well settled that a primary purpose for enacting the Shipping Act was to achieve uniformity of treatment among shippers. ${ }^{57}$ This goal can be achieved only if all shippers are required to pay the same rates for transportation of the same types of property. Because rebates are designed to refund to the shipper a portion of the established price, their effect is to enable certain shippers to transport their goods at a price lower than that set in the tariff. Clearly then, acceptance of a rebate ought to be unlawful if the stated purpose of the statute is to be effectuated.

[It] provides that it shall be unlawful for any common carrier by water, . . . to allow the transportation of property at less than the regular rates then in force by the common carrier by means of false billing or other misclassification of freight, false claims, etc. Thus it will be seen, that while the carrier is prohibited from allowing favoritism or partiality as among competing shippers, the carrier itself is afforded no protection against the practice of an unscrupulous shipper, forwarder, broker, or other delivering goods to the carrier for transportation in deliberately misclassifying packages of freight for the purpose of obtaining a lower transportation rate at the expense of the carrier.

The Senate measure, therefore, strengthens this portion of the Shipping Act of 1916 , and goes further in providing that such a practice shall neither be engaged in by a common carrier by water nor by any shipper, . . . thereby effectually removing the means left open to dishonest shippers or consignees whereby they may take advantage not only of their competitors who do not indulge in the practice of false billing and misclassification in order to receive a lower transportation rate for their freight, but also of the carrier itself by depriving the carrier of a rightful source of revenue.

Carriage of Military Cargo, 1967 Am. Mar. Cas. 443, 462 (F.M.C. 1967) (quoting H.R. REP. No. 2205, 74th Cong., 2d Sess. 1-2 (1936)).

52. 316 F.2d 381 (D.C. Cir. 1963).

53. Id. at 385 .

54. Id. at 385 n.11.

55. See note 32 supra and accompanying text.

56. See notes 36-40 supra and accompanying text.

57. See note 27 supra and accompanying text. 
One of the elements of liability under section 16 is that the action must be taken knowingly and willfully. ${ }^{58}$ If the offense consists of the use of an unfair device other than those specifically mentioned, the requirement would appear to be that the shipper must have had knowledge of its legal duty to pay the charges set in the tariff, and that the shipper willfully proceeded to use the unfair device in order to obtain transportation at a lower rate. Since the shipper is deemed to have received constructive notice of the information contained in a tariff when it is filed by the carrier with the FMC, ${ }^{59}$ and since the shipper is presumed to know the law as stated in the Shipping Act, ${ }^{60}$ so long as the shipper is cognizant of the probable effect of the unfair device, the requirement that it act knowingly should present no real difficulty in holding the shipper liable under section 16 . Thus if the shipper in fact knowingly obtains transportation at a cost lower than the filed rate, a court may readily find that the shipper intended to do so, and that therefore the act was willful.

A second requirement of section 16-that the device be "unjust or unfair" - is not so easily met. There is some authority for the view that not all rebates fall within the proscription of section 16. In United States $v$. Peninsular \& Occidental Steamship Co. ${ }^{61}$ the court held that if no attempt was made to conceal the rebate and if the rebate was accepted under circumstances permitting competitors to ascertain that such a procedure had been followed, the shipper would have committed no offense under section 16. ${ }^{62}$ Although the court did not furnish detailed analysis, the decision apparently turned on the phrase "unjust or unfair." While a rebate is obviously a means by which one shipper might obtain transportation for less

58. See text accompanying note 49 supra. In a case involving false classifications, one court held that the statute was violated only if the false classification, which was used to obtain transportation of shipments at unauthorized low rates, was made knowingly and willfully. Royal Netherlands S.S. Co. v. Federal Maritime Bd., 304 F.2d 938 (D.C. Cir. 1962).

59. See note 31 supra and accompanying text. See Black Diamond S.S. Corp. v. S.H. Kress \& Co., 157 Misc. 360, 284 N.Y.S. 310 (App. Term 1935) (per curiam) (shipper not permitted to enforce contract for transportation at less than the rate filed by the carrier, despite the fact that shipper had no knowledge of the published rates).

60. See note 31 supra and accompanying text.

61. 208 F. Supp. 957 (S.D.N.Y. 1962).

62. Id. at 958 . The matter reached the court on the motion of two defendants to have the second count of a two-count information dismissed on the grounds that their alleged act did not constitute an offense. The disputed count is quoted by the court as follows:

On or about the 27th day of October, 1960, in the Southern District of New York, JOHN $\mathrm{H}$. FAUNCE, INC. and VINCENT WORTMAN, an officer, agent and employee thereof, defendants, unlawfully, wilfully and knowingly did obtain and attempt to obtain transportation by water in foreign commerce for property at less than the rates and charges which would otherwise be applicable by an unjust and unfair device and means, to wit, the payment of a rebate of a portion of certain shipping charges by THE PENINSULAR AND OCCIDENTAL STEAMSHIP COMPANY, a common carrier by water engaged in foreign commerce, and its agent, MAC GREGOR SHIPPING COMPANY, INC. to JOHN H. FAUNCE, INC.

Id. at 957-58. 
than the price quoted to his competitors, the court believed the rebate should not be considered unfair if the fact of the rebate is open to public scrutiny; in such cases, the court felt that market pressures from competing shippers would be sufficient to alleviate any possible unfairness. ${ }^{63}$ However, it is not likely that rebates would ever be granted openly since the carrier would find it necessary to conceal the rebate in some way in order to avoid section 14 or section 18(b)(3) liability, ${ }^{64}$ and this concealment would be sufficient to establish the shipper's liability under section 16 . Thus, a shipper who is powerful enough to demand rebates from a carrier, thereby disadvantaging its competitors, is also apt to incur liability for this unfair use of its bargaining power. Because of this, the Peninsular limitation would have little effect in most cases. ${ }^{65}$

More importantly, restricting the applicability of section 16 to those situations where there has been an attempt to conceal the fact of the rebate is clearly inconsistent with the purpose of the Shipping Act to eliminate rebating, rate discrimination and collusive pricing, ${ }^{66}$ or with the strict enforcement policy that has been applied to the requirement that the full

63. The court relied heavily on an opinion by Judge Learned Hand construing identical language contained in the second paragraph of $\S 16$, which forbids carriers to allow any person to obtain transportation for less than the established rates through the use of such a device. According to Judge Learned Hand,

[t]he law did not forbid all concessions to a shipper; apparently it assumed that if these were above board, and known or ascertainable by competitors, the resulting jealousies and pressure upon the carrier would be corrective enough. But it did forbid the carrier to grant such favors, when accompanied by any concealment.

Prince Line, Ltd. v. American Paper Exports, Inc., 55 F.2d 1053, 1055 (2d Cir. 1932), quoted in 208 F.Supp. at 958.

On a motion for reargument, the court in Peninsular considered the situation where a shipper and a carrier act in conjunction to deceive other shippers through the use of unfair devices. The court recognized legislative history indicating an intent to protect innocent carriers from being defrauded by a shipper, but rejected the argument that only the carrier would be liable. $208 \mathrm{~F}$. Supp. at 958-59. In reaching this decision, the court relied on a house report stating that the practice of obtaining transportation at a lower rate is forbidden to both the carrier and the shipper. Competing shippers are protected from dishonest shippers, but this protection also extends to the carrier itself. Id. at 959 n.1 (citing H.R. REP. No. 2205, 74th Cong., 2d Sess. 2 (1936)).

64. See notes $36-40$ supra and accompanying text.

65. Although the proposition that shippers may be held strictly liable under $\S 16$ for accepting a rebate appears unexceptionable, one court has refused to accept an interpretation requiring strict liability. In the Hohenberg Brothers case, the court stated:

Hohenberg has argued that we cannot affirm the Commission unless we hold that obtaining a lower rate, without more, constitutes a violation of Section 16 . We hold no such thing. Hohenberg's actions in this case went well beyond a mere public request that it be granted lower rates. We affirm because of the way in which lower rates were obtained, not because of the mere fact that they were.

316 F.2d at 385 . But this need not be interpreted as an absolute rejection of the notion of strict liability. Because the defendant's actions were found to be the equivalent of false billing, the element of concealment was present. Thus, it was not necessary for the court to go beyond the Peninsular decision in order to include rebates unaccompanied by acts of concealment.

66. See notes 27,34 supra and accompanying text. 
tariff rate be charged to each shipper. ${ }^{67}$ Both of these factors would indicate that a broader construction of section 16 is more appropriate. The courts should not have to depend on ordinary market pressures to correct, over a period of time, the inequalities in effective rates charged to competing shippers. The "plain meaning" approach to statutory interpretation does not necessarily yield the proper result, and, as one court has observed, "Judge Learned Hand was not preaching novel doctrine when he instructed years ago: "There is no surer way to misread any document than to read it literally." "68 This was thought to be especially true when a literal reading produced an anomalous result. ${ }^{69}$

It should be noted that the Peninsular approach may make considerable sense when applied to interstate commerce. The provision of the Shipping Act governing rates to be charged by carriers in interstate commerce merely requires that the maximum rate be filed, and that just and reasonable rates be enforced. These carriers are forbidden to collect a greater compensation for such transportation services. ${ }^{70}$ Apparently, ordinary market pressures were considered sufficient to insure the equitable treatment of shippers with respect to transportation in interstate commerce. Because a rebate involves the collection of a lesser amount than the filed rate, it is only in cases of attempted concealment that a rebate might be regarded as a violation of the requirement that rates charged by a carrier be "just."

However, the filing requirement is quite different for carriers engaged in foreign commerce. The carrier in foreign commerce must file with the FMC, not a maximum rate, but one single rate to be charged for all transportation between United States and foreign ports. ${ }^{71}$ Section $18(b)(3)$ prohibits a carrier in foreign commerce from collecting either more or less than the rate set forth in the filed tariff for transportation services, and rebates not included in the rate schedule are expressly forbidden. ${ }^{72}$ Thus, in the context of foreign commerce, there is no indication of a legislative intent to leave the enforcement of equal treatment for all shippers to the normal pressures of the market. In view of this difference in the language of the

67. See notes 33-35 supra and accompanying text.

68. Federal Maritime Comm'n v. DeSmedt, 366 F.2d 464, 469 (2d Cir.) cert. denied, 385 U.S. 974 (1966) (quoting Judge Learned Hand, Guiseppi v. Walling, 144 F.2d 608, 624 (2d Cir. 1944) (concurring opinion), aff'd sub nom. Gemsco, Inc. v. Walling, 324 U.S. 244 (1945)). But see Associated Wholesale Grocers, Inc. v. United States, 272 F. Supp. 274,277 (D. Kan. 1967) (arising under the Interstate Commerce Act) ("[r]ate and tariff items are promulgated for laymen to use in their ordinary affairs and where the language is plain they should be given their plain meaning") (footnotes omitted).

69. Federal Maritime Comm'n v. DeSmedt, 366 F.2d 464, 470 (2d Cir.), cert. denied, 385 U.S. 974 (1966).

70. 46 U.S.C. \& 817(a) (1970). See note 30 supra.

71. 46 U.S.C. $\$ 817(b)(1)(1970)$.

72. Id. $\$ 817(b)(3)$. 
Shipping Act, a more justifiable approach than that applied in the Peninsular case ${ }^{73}$ would be to hold that any shipper in foreign commerce that accepts a rebate and thereby obtains transportation at a cost less than or different from the published rate is liable under section $16 .{ }^{74}$

Regardless of whether the ambiguity in the statute is resolved in favor of liability on the part of a shipper who accepts a rebate, a shipper who induces a carrier to pay a rebate also may be prosecuted as an aider and abettor in the commission of a crime. ${ }^{75}$ The prosecution would be based on a statute that provides that any person who aids and abets or induces an offense against the United States is punishable as a principal. ${ }^{76}$ Under the statute, the common law distinctions between principals and accessories are eliminated and all parties are made subject to the same liability, regardless of whether the offense is a felony or a misdemeanor. ${ }^{77} \mathrm{~A}$ person charged with aiding and abetting will be punishable as a principal if he consciously shares in a criminal act, even in the absence of an actual conspiracy. ${ }^{78}$ In order to establish the offense, the government is merely required to show

73. In Peninsular the government had alleged that the defendant had used unjust means to obtain transportation at less than the rate filed by the carrier with the FMC. However, the court did not address the differences in the filing requirements imposed upon carriers in foreign as opposed to interstate commerce. On the motion for reargument, the court indicated that it was not concerned with any comparison between the treatment accorded to various shippers by the carrier. Its concern was only with the "disequality between the rates at which defendants obtained or attempted to obtain transportation, and the rates that "would otherwise be applicable." "' 208 F. Supp. at 959 (quoting 46 U.S.C. $§ 815$ (1970)).

74. It should be noted that the Shipping Act does not prevent a shipper from seeking a more favorable rate. In this regard, he is restricted only by the statute's prohibitions against preference, prejudice and discrimination, and by the requirement that the means employed by the shipper not be unfair or unjust within the meaning of $\S 16$. Thus, it has been said that the basic purpose of $\$ 16$ is "to insure adherence by a carrier to his publicly announced rates, not to foreclose any change in those rates at the behest of an individual shipper." Carriage of Military Cargo, 1967 Am. Mar. Cas. 443, 461 (F.M.C. 1967).

In a senate report containing recommendations relating to water carriers engaged in foreign trade, it was stated:

It is not the purpose of this recommendation to prevent steamship lines from promptly lowering their rates to meet competitive conditions and thus to favor American exporters, who, in competing with foreign markets, often find it necessary in order to close their contracts to have quoted an immediate and favorable rate; but the purpose of the law should be to protect the shipper against any unreasonable high rate with which the combination lines may have within their power, by virtue of their agreements and conference arrangements, arbitrarily to impose in the absence of Government supervision and control.

S. REP. No. 689 , supra note 27 , at 10 . Thus, it is not expected that the tariff rate will never be changed. The statute is merely intended to prohibit certain favored shippers from paying a lower rate while the tariff rate ostensibly remains in effect. Carriage of Military Cargo, 1967 Am. Mar. Cas. 443, 462 F.M.C. 1967). Clearly, if the filed rate is changed in accordance with proper procedures, 46 U.S.C. $\$ 817(b)(2)(1970)$, then a shipper who pays the new lower rate has not violated any provision of the Shipping Act.

75. See Peninsular, 208 F. Supp. at 958-59.

76. 18 U.S.C. $\$ 2$ (1970). This section provides:

(a) Whoever commits an offense against the United States or aids, abets, counsels, commands, induces or procures its commission, is punishable as a principal.

(b) Whoever willfully causes an act to be done which if directly performed by him or another would be an offense against the United States, is punishable as a principal.

77. United States v. Bryan, 483 F.2d 88, 95 (3d Cir. 1973).

78. Pereira v. United States, 347 U.S. 1, 11-12 (1954); United States v. Valencia, 492 F.2d 1071, 1074 (9th Cir. 1974). 
some affirmative participation by the person charged which at least served to encourage the perpetrator. ${ }^{79}$

Naturally, in order for the shipper to be exposed to such liability, the carrier would have to have committed a criminal offense. A violation of section 14 of the Shipping Act ${ }^{80}$ is a criminal misdemeanor, and thus could subject both the carrier and shipper to liability. However, the offense described in section $18(b)(3)^{81}$ merely subjects the carrier to civil liability. Therefore, the aiding and abetting statute would not be applicable in cases arising under that provision.

\section{Possible Resolution of the Ambiguity by the FMC}

It is conceivable that the FMC could resolve the ambiguity in the statute with regard to a shipper's liability for the acceptance of a rebate through the exercise of its authority to establish and enforce regulations. The FMC is empowered by the Shipping Act to make such rules and regulations as may be necessary to carry out the other provisions of the statute. ${ }^{82}$ Such an express delegation of rulemaking power should be construed to grant the agency the authority to establish regulations and substantive rules that are reasonable in light of the purposes of the enabling legislation. ${ }^{83}$ Thus, it appears that the FMC could resolve the issue of a shipper's liability by promulgating a regulation holding the acceptance of a rebate by a shipper that enables it to obtain transportation for less than is provided in the tariff to be a violation of section 16 . A substantive regulation of this type would be consistent with the purposes of the Shipping Act in that it would promote uniformity in the treatment of both carriers and shippers, prevent discrimination and discourage rebating. ${ }^{84}$ In addition, such a regulation would be

79. United States v. Wiebold, 507 F.2d 932, 934 (8th Cir. 1974); United States v. Thomas, 469 F.2d 145, 147 (8th Cir. 1972), cert. denied, 410 U.S. 957 (1973).

80. See notes $38-40$ supra and accompanying text.

81. See notes $36-37$ supra and accompanying text.

82. 46 U.S.C. $\$ 841$ a (1970).

83. B. SCHWARTZ, ADministrative LAw $\S 56$, at 149 (1976); see Mourning v. Family Publications Serv., Inc., 411 U.S. 356, 369 (1973).

Statutory language almost identical to the enabling provision of the Shipping Act has been construed to authorize the Federal Trade Commission to promulgate substantive rules. National Petroleum Refiners Ass'n v. FTC, 482 F.2d 672, 685 (D.C. Cir. 1973), cert. denied, 415 U.S. 951 (1974). The court was construing section 6(g) of the Federal Trade Commission Act which provides that the FTC "shall also have power . . . to make rules and regulations for the purpose of carrying out the provisions . . . of this title." 15 U.S.C. \$ 46 (1970 \& Supp. V 1975).

Authority to issue such rules is consistent with the broad legislative purposes underlying the establishment of regulatory commissions. See B. SchwarTZ, supra at $\$ 56$, at 150 . The exercise of that rulemaking power represents an appropriate means of effectuating those goals because it would enable the commissions to function more efficiently and would serve to bring about more uniform results in particular cases. Id.

84. See notes 27-29 supra and accompanying text. 
reasonably related to the purposes of the enabling legislation; the statutory language is simply too ambiguous to provide effective enforcement. A regulation such as this which does not exceed the authority of the agency's generic statute assumes the force of law, and would be applied by the courts as if it were a part of the statute under which it issues. ${ }^{85}$

As an alternative to issuing a substantive regulation, the FMC could promulgate an interpretative rule ${ }^{86}$ clarifying the applicability of section 16 to rebates. The Commission would be acting within its authority in defining the term "unfair device" to include the acceptance of a rebate that enables a shipper to obtain transportation for less than the filed rate, regardless of the presence or absence of an act of concealment. Such a clarification is arguably necessary in order to insure the uniform application of the provision.

In addition to its rulemaking power, the Commission is authorized to investigate alleged violations of the Shipping Act and to issue appropriate orders regarding any practice requiring FMC approval. ${ }^{87}$ The FMC possesses primary jurisdiction over persons subject to the Shipping Act and is responsible for obtaining and enforcing compliance with its provisions. ${ }^{88}$ In this capacity, the Commission's function is to interpret and apply existing statutory provisions, rather than to promulgate new regulations. Deference will be paid to agency decisions involving matters within the agency's special expertise. ${ }^{89}$ This is particularly true where, as in the case of the FMC, the interests of foreigners are affected ${ }^{90}$ and there is thus a greater

85. Pacific Coast European Conf. v. Federal Maritime Comm'n, 376 F.2d 785, 790 (D.C. Cir. 1967).

86. A distinction may be drawn between substantive and interpretative rules. Substantive regulations are promulgated pursuant to statutory authority and carry the same force and legal effect as a statute. B. SchWARTz, supra note 83 , at $\$ 59$. An interpretative regulation, on the other hand, is merely a clarification of existing laws or regulations in the form of a statement of the construction adopted by the agency. Gibson Wine Co. v. Snyder, 194 F.2d 329, 331 (D.C. Cir. 1952). Unlike a substantive regulation, an interpretative rule does not assume the force of law. However, interpretative rules are of tremendous practical significance due to the great weight attached to them by the courts. B. ScHWARTz, supra note 83 , at $\S 58$. Interpretative rules, "while not controlling on the courts by reason of their authority, do constitute a body of experience and informed judgment to which courts and litigants may properly resort for guidance." Skidmore v. Swift \& Co., 323 U.S. 134, 140 (1944).

87. 46 U.S.C. $\$ 821$ (1970); Pacific Coast European Conf. v. Federal Maritime Comm'n, 537 F.2d 333, 337 (9th Cir. 1976).

88. Federal Maritime Comm'n v. New York Terminal Conf., 262 F. Supp. 225, 228 (S.D.N.Y. 1966), aff'd, 373 F.2d 424 (1967).

89. American Union Transp., Inc. v. United States, 257 F.2d 607, 612 (D.C. Cir.), cert. denied, 358 U.S. 828 (1958) (distinguishing the services of a broker from a freight forwarder).

90. See Carnation Co. v. Pacific Westbound Conf., 336 F.2d 650, 663 \& n.23 (9th Cir. 1964), rev'd on other grounds, 383 U.S. 213 (1966) (citing D. MARX, INTERNATIONAL SHIPPING CARTEls: A StUdy OF INDUSTRIal Regulation by Shipping Conferences 137 (1953)). Through the Shipping Act, the FMC is able to regulate foreign carriers which operate on routes 
than usual need for consistency and uniformity of interpretation. As one court observed:

Congress, in setting up this elaborate system of controlled cooperation in respect to rates, shipping conditions, and other matters relating to carriers in foreign trade, and committing its regulation and enforcement to a special commission, contemplated that this commission would become familiar with the problems of foreign water-borne commerce and develop considerable expertise in connection therewith.

The Act lists many standards whose application requires more than ordinary familiarity with ocean transportation. ${ }^{91}$

For these reasons, the principle is now well established that an initial submission to the federal agency will be required in cases raising issues of fact which demand an understanding of a specialized subject matter beyond the conventional experience of judges, and in cases requiring the exercise of administrative discretion..$^{92}$ In order to achieve more uniform and consistent regulation of the industry, preliminary resort to the agency for a determination of the facts is necessary even in those situations where the facts will later serve as a basis for a judicial determination of legal consequences. ${ }^{93}$

Despite this, one court has ruled that a violation of that portion of section $18(b)(3)$ which forbids a carrier to accept a lesser price than the tariff rate, is not a matter requiring the special expertise of the FMC. ${ }^{94}$ It was the defendant's contention in that case that in deference to the Commission's expertise in the field of tariff interpretation and administration the court should refrain from taking further action until proceedings could be instituted before the FMC. ${ }^{95}$ This argument was rejected, and it was held that preliminary resort to the FMC was not required. ${ }^{96} \mathrm{It}$ was noted that administrative proceedings ${ }^{97}$ are not a prerequisite to a civil action by the United States under section $18(b)(6)^{98}$ to recover penalties for certain Shipping Act

between the United States and foreign countries to a certain degree. Carnation, 336 F.2d at 663 . See, e.g., 46 U.S.C. \$ 813 (1970).

91. Carnation Co. v. Pacific Westbound Conf., 336 F.2d 650, 661 (9th Cir. 1964), rev'd on other grounds, 383 U.S. 213 (1966) (footnote omitted) (deciding what agreements will, or will not, operate to the detriment of the commerce of the United States).

92. Far East Conf. v. United States, 342 U.S. 570, 575-76 (1952). See also United States v. Morgan, 307 U.S. 183, 191 (1939); United States Navigation Co. v. Cunard S.S. Co., 284 U.S. 474, 481, 485-88 (1932).

93. Far East Conf. v. United States, 342 U.S. 570, 574-75 (1952).

94. United States v. Pan Am. Mail Line, Inc., 359 F. Supp. 728, 732 (S.D.N.Y. 1972).

95. Id. at 731 .

96. Id. at 732 .

97. Section 22 provides for complaints to the FMC and authorizes the Commission to institute investigations on its own initiative and to award reparations if the violations are established. 46 U.S.C. $\$ 821$ (1970). Section 23 requires a full hearing prior to any orders by the FMC with respect to violations. Id. \$ 822. See United States v. Pan Am. Mail Line, Inc., 359 F. Supp. 728,732 (S.D.N.Y. 1972).

98. 46 U.S.C. $\$ 817(b)(6)(1970)$. 
violations. ${ }^{99}$ Because the case merely involved the question of whether an amount different from the filed tariff had been collected by the carrier, it was held that the case involved no technical language requiring expert construction, no complicated facts requiring expert analysis and no need for uniform decisional law. ${ }^{100}$ Thus, the court believed the issue could appropriately be decided in the judicial proceeding.

Even if the mechanical application of the specific statutory language that is required in cases involving section 18(b)(3) may be regarded as sufficient to give the courts and the FMC concurrent jurisdiction, ${ }^{101}$ considerations of subject matter expertise and uniformity still point to the regulatory agency as the preferable forum. If section $18(\mathrm{~b})(3)$ determinations do not involve the FMC's special expertise, it is clear that section 16 determinations do. A shipper's liability under section 16 is dependent upon the interpretation to be given to the term "unfair device." The Commission's expertise in the field of international shipping would render that body much more qualified to determine whether the effects of a particular type of rebate are likely to result in the unfair treatment of competing shippers. ${ }^{102}$

Nonetheless, it might be argued that the issue of shipper liability is one which should not be left to resolution by the FMC. In Alcoa Steamship Co. v. Federal Maritime Commission, ${ }^{103}$ the court reviewed the legislative history of the Shipping Act and found that Congress intended for the FMC to possess fewer investigatory and regulatory powers than those found in other federal agencies regulating commerce. This was believed to be necessary because maritime carriers differ from domestic railroads in that they are in direct competition with foreign carriers. Congress was concerned with the possibility that American carriers might be placed in a disadvantageous position in relation to their foreign competitors if the shipping industry were to become over-regulated. While the Alcoa Steamship case concerned the

99. United States v. Pan Am. Mail Line, Inc., 359 F. Supp. 728, 732 (S.D.N.Y. 1972).

100. Id.

101. See Jaffe, Primary Jurisdiction, 77 Harv. L. Rev. 1037 (1964).

102. The standard used by courts in reviewing agency decision lends further support to the view that these matters are appropriate for an initial agency determination. Under $\S 10(e)$ of the Administrative Procedure Act, a reviewing court may set aside an agency's findings and conclusions if they are found to be arbitrary, capricious, an abuse of discretion, or unsupported by substantial evidence. 5 U.S.C. $\$ 706$ (1970); Consolo v. Federal Maritime Comm'n, 383 U.S. 607,619 (1966). According to the Supreme Court, Congress had several definite motives in adopting this standard of review: the reviewing courts were to be relieved of the time consuming task of weighing the evidence, the expertise of the administrative tribunal would be given effect, and uniformity of interpretation would be promoted. Id. at 620-21.

103. 348 F.2d 756 (D.C. Cir. 1965). That case dealt with a procedural matter, i.e., the power of the FMC to inspect business records. Such power was expressly conferred on the ICC but not mentioned with regard to the FMC by the Shipping Act. According to Chief Judge Bazelon, "[w]here Congress has consistently made express its delegation of a particular power, its silence is strong evidence that it did not intend to grant the power." Id. at 758. 
procedural authority of the FMC, the court would also impose limits on the Commission's substantive powers. According to the court, the FMC is empowered to adopt only those rules necessary for the substantive regulation required by the Shipping Act, and this power is not to be exercised in such a manner as to place an unequal burden on United States carriers in relation to their foreign competitors. ${ }^{104}$

Despite the court's concern, a clarification of the applicability of section 16 to rebates does not appear to pose any danger to the delicate competitive balance in the international shipping industry. The susceptibility of American shippers to regulation by the FMC has already been established. A clarification of the meaning of section 16 would merely serve to enhance the uniform application of the statute. Domestic carriers are prohibited from allowing such rebates by several provisions of the Shipping Act. ${ }^{105}$ The prohibitions are also applicable to foreign carriers. Under section $14 \mathrm{a}$, a foreign carrier may be refused the right of entry into any United States port until the violation ceases. ${ }^{106}$ The FMC is granted the authority to determine whether a foreign carrier has violated the statute's prohibition against the granting of deferred rebates. ${ }^{107}$

While the FMC would appear to be the most appropriate body to ascertain the proper application of section 16 to shippers' receipt of rebates, it has not yet exercised its rulemaking power to set forth guidelines to be used in determining the applicability of this particular provision. Instead, it has sought to achieve the desired uniformity of treatment for shippers through the use of settlement agreements, under which shippers have voluntarily agreed to pay fines. ${ }^{108}$

Although the resolution of the ambiguity in section 16 by the FMC, either by regulation or by order, is both logical and supported by ample authority, one court has held that the Commission lacks authority to regulate the conduct proscribed in section 16. United States v. American Union Transport, Inc. ${ }^{109}$ involved alleged violations by a carrier of that portion of section 16 that makes it a misdemeanor for a carrier to allow any person to obtain transportation at less than the regular rate by any unfair device. ${ }^{110}$

104. Id. at 759-62. The Shipping Act contains an express prohibition addressed to common carriers by water in foreign commerce against the collection of any rate which is unjustly prejudicial to exporters of the United States as compared with their foreign competitors. 46 U.S.C. $\$ 816$ (1970).

105. See notes $36-40$ supra and accompanying text.

106. 46 U.S.C. § 813 (1970).

107. Id.

108. See notes 11-14 supra and accompanying text.

109. 232 F. Supp. 700 (D.N.J. 1964).

110. The court quoted the statutory language of 46 U.S.C. $\S 815$ as follows:

It shall be unlawful for any common carrier by water . . . either alone or in conjunction with any other person, directly or indirectly- 
Although the court recognized the FMC's power to determine the reasonableness of rates charged by carriers, ${ }^{111}$ it felt that section 16 merely addressed itself to prohibiting evasions of the established rates. Because such conduct is specifically prohibited by the statute, the court believed there was no need for special expertise, and the FMC was seen to possess no authority to regulate in this area. ${ }^{112}$ Apparently, this conclusion was founded upon the court's observation that the Shipping Act contains no explicit grant of power to the FMC that would enable the agency to determine whether a violation of section 16 has occured. ${ }^{113}$ However, such a conclusion is inconsistent with the court's earlier citation to several provisions of the Shipping Act that empower the FMC to investigate any violation of the statute-including section 16-and to issue an order to remedy any violation found to exist after a hearing. ${ }^{114}$

The validity of the American Union Transport decision and its applicability to that part of section 16 which provides that a shipper may not obtain transportation at less than the tariff rate by any unfair device is subject to serious question. ${ }^{115}$ The major issue in the case was whether the FMC has exclusive jurisdiction over section 16 violations. Thus, once the court determined that it at least had concurrent jurisdiction with the agency, its

Second, to allow any person to obtain transportation for property at less than the regular rates or charges then established and enforced on the line of such carrier by means of false billing, false classification, false weighing, false report of weight, or by other unjust or unfair device or means.

Whoever violates any provision of this section shall be guilty of a misdemeanor punishable by a fine of not more than $\$ 5,000$ for each offense.

232 F. Supp. at 701. The section quoted by the court was amended in 1972, Act of Aug. 29, 1972, Pub. L. No. 92-416, 86 Stat. 653 (1972) (codified at 46 U.S.C. $\$ 815$ (Supp. V 1975)), and the provision was changed to provide for a civil remedy.

The current $\S 16$ imposes criminal sanctions upon carriers granting unreasonable preference to any particular person or locality, or inducing an insurance company not to give a competing carrier as favorable a rate of insurance. A corresponding civil penalty is applied to both shippers and carriers engaging in the use of unfair devices to enable a shipper to obtain transportation at less than the lawful rate. 46 U.S.C. $\$ 815$ (Supp. V 1975).

111. Sections 17 and 18 authorize the FMC to determine the reasonableness of a carrier's rates and practices, and to prescribe reasonable and just rates and regulations. 46 U.S.C. $\$ \S$ 816,817 (1970).

112. 232 F. Supp. at 703. Compare with United States v. Pan Am. Mail Line, Inc., 359 F. Supp. 728 (S.D.N.Y. 1972). See notes 94-102 supra and accompanying text.

113. 232 F. Supp. at 703. The court compared $\S 14 \mathrm{a}$ under which the FMC is expressly authorized to determine the existence of a violation of $\S 14$, to the absence of any such express enabling provision with respect to $\S 16$. Id.

114. Id. at 702. See 46 U.S.C. $\$ \S 821-829$ (1970).

115. A separate violation of $\S 16$ was charged against the shipper for using false measurements and false billing to obtain transportation at less than the rate otherwise applicable. However, the court's decision deals merely with the carrier's motion for dismissal of the information on the ground that the FMC had exclusive, primary jurisdiction. 232 F. Supp. at 701. 
further statements concerning the Commission's powers became dicta. Moreover, there is a clear indication that its dicta was overly broad.

The carrier in the case argued that its conduct in knowingly accepting false measurements supplied by the shipper was not specifically prohibited by section 16 and that if such behavior is to constitute an offense under that provision, it would have to fall within the purview of the general prohibition against the use of "any other unjust or unfair device or means" to obtain transportation at less than the established rate. ${ }^{116}$ It was the carrier's contention that the special expertise of the FMC should be consulted in order to determine whether the general language of section 16 should be applied to this particular offense. ${ }^{117}$ This theory was rejected by the court on the ground that the proper interpretation of the statute's intent presented only a question of law. The court believed itself to be as capable as the FMC to determine the meaning and intent of the statute. ${ }^{118}$ But even if the court is correct in this matter, it is not clear that its reasoning should be extended to cover the application of section 16 to rebates.

The false measurements with which the court was concerned are essentially equivalent to false billing, which is specifically prohibited by the statute. Thus, even if the court is competent to make this comparison and determine that false measurements are "unfair devices," it still may not be equally competent to determine whether a rebate should similarly fall within that category. Rebates have no analogue in the statute's list of specifically enumerated offenses; the special expertise of the FMC is required to gauge the effects of the practice on competing shippers in foreign commerce. The dicta of American Union Transport should not be seen to preempt the FMC from assuming jurisdiction to act, either by rule or order, to clarify the existing ambiguity in section 16 . Even if the courts are not willing to defer to the exclusive jurisdiction of the Commission, the principle of concurrent jurisdiction should be recognized. In view of the FMC's specialized expertise, the wisdom of any decision that would deny the agency a role in the interpretation of the Shipping Act is questionable.

\section{COMPARISON WITH THE INTERSTATE COMMERCE ACT}

The Shipping Act was passed by Congress with the intent that it would parallel in its own field the regulation of commerce provided under the Interstate Commerce Act. ${ }^{119}$ It was expected that the comprehensive Ship-

116. Id. at 704 .

117. Id.

118. Id.

119. 49 U.S.C. \& § 1-27, 301-327, 901-1022, 1231-1240 (1970 \& Supp. V 1975); see Ambler v. Bloedel Donovan Lumber Mills, 68 F.2d 268, 269 (9th Cir. 1933). The senate report accompanying the enactment of the Shipping Act observed:

While the part of the bill relating to the regulation of carriers by water differs necessarily and materially from the corresponding provisions of the interstate 
ping Act would stand in the same position with respect to common carriers by water as that held by the Interstate Commerce Act in relation to interstate carriers by land. Because the Interstate Commerce Act had already been in effect for a substantial period of time, the application of its provisions to a wide variety of situations had been the subject of numerous judicial opinions. ${ }^{120}$ In view of the similarities between the two statutes, the Supreme Court observed:

In its general scope and purpose, as well as in its terms, that act [the Shipping Act] closely parallels the Interstate Commerce Act; and we cannot escape the conclusion that Congress intended that the two acts, each in its own field, should have like interpretation, application, and effect. It follows that the settled construction in respect of the earlier act must be applied to the later one, unless, in particular instances, there be something peculiar in the question under consideration, or dissimilarity in the terms of the act relating thereto, requiring a different conclusion. ${ }^{121}$

Thus, it is only in those instances where the unique problems of transportation by water require specialized treatment that the traditional concepts

commerce act, the difference is not so radical that the administration and enforcement provisions of the latter act and the nearly 30 years' experience of the Interstate Commerce Commission cannot be adapted with slight modifications to the purposes of this bill.

S. REP. No. 689 , supra note 27 , at 12 . The Interstate Commerce Act is applicable to common carriers engaged in the "transportation of passengers or property wholly by railroad, or partly by railroad and partly by water when both are used under a common control, management, or arrangement for a continuous carriage or shipment" from one state to another or from the United States to or from a foreign country, but only insofar as such transportation takes place within the United States. 49 U.S.C. $§ 1(1)$ (1970). It is not applicable to transportation wholly within one state. $I d$. $\$ 1(2)$.

120. See, e.g., Consolo v. Federal Maritime Comm'n, 383 U.S. 607 (1966); United States Navigation Co. v. Cunard S.S. Co., 284 U.S. 474 (1932). In Consolo, the Court held that if the Interstate Commerce Act allowed a shipper to bring a direct review proceeding to challenge the adequacy of a reparation award granted by the ICC, then a similar action should be permitted to challenge an award issued by the FMC, subject only to any special provisions applicable to maritime cases. Id. at 613. Another court observed that the Interstate Commerce Act allowed carriers the right to recover the full transportation charges specified in the approved tariff, despite an agreement to transport the cargo at a lesser rate. Maritime Serv. Corp. v. Sweet Brokerage De Puerto Rico, Inc., 537 F.2d 560, 562 (1st Cir. 1976). This right to recover had been inferred from an express requirement that the carrier charge only the established rate, and from the congressional policy against unjust discrimination. Because a similar congressional policy against discriminatory rates is found in the Shipping Act's requirement that carriers enforce the filed tariff, it was held that the same inferences should be drawn to give the carrier a right to recover under the Shipping Act. Id. at 562-63. See also Prince Line, Ltd. v. American Paper Exports, Inc., 55 F.2d 1053, 1055-56 (2d Cir. 1932).

121. United States Navigation Co. v. Cunard S.S. Co., 284 U.S. 474, 481 (1932). The Court then proceeded to review various provisions of the Shipping Act, and concluded that their close parallelism with the Interstate Commerce Act justified the application to both Acts of similar principles of construction and administration. Id. at 484. 
governing domestic common carriers will not be regarded as applicable to international commerce by water. ${ }^{122}$

The similarities between section 16 of the Shipping Act and section 6(7) of the Interstate Commerce Act ${ }^{123}$ were noted in Prince Line, Ltd. $v$. American Paper Exports, Inc. ${ }^{124}$ The court acknowledged the numerous judicial opinions construing this provision of the Interstate Commerce Act which have held: first, that the rate filed by the carrier is the only lawful charge, ${ }^{122}$ second, that deviation from the lawful charge is not to be allowed under any pretext, ${ }^{126}$ third, that the carrier will not be permitted to reduce the amount payable by contract, ${ }^{127}$ fourth, that the carrier will not be precluded by his own act or omission from enforcing payment of the full amount, ${ }^{128}$ and finally, that because the tariff embodies the congressional policy of preventing unjust discrimination, the rate will be enforced even in cases where it works a hardship. ${ }^{129}$ In view of the similarly explicit expression of legislative intent behind the Shipping Act, that the established rate should be the legal rate that the carrier is required to charge and the shipper is required to pay, each of these considerations was seen to apply with equal force to section $16 .{ }^{130}$

The Prince Line case dealt with that portion of section 16 that makes it unlawful for a carrier to allow any person to obtain transportation at less than the regular established rate by any unfair device or means. ${ }^{131}$ These same considerations would appear to be applicable to that part of the provision that prohibits a shipper from obtaining transportation for less than the published rate through the use of an unfair device. ${ }^{132}$ However, in Hohenberg Brothers, which considered an alleged offense by a shipper under that provision, the court refused to entertain a comparison to the

122. United States v. Stephen Bros. Line, 384 F.2d 118, 122 (5th Cir. 1967).

123. 49 U.S.C. $\$ 6(7)(1970)$. Section $6(7)$ provides:

No carrier . . . shall engage or participate in the transportation of passengers or property . . . unless the rates . . . have been filed and published ...., nor shall the carrier charge or demand or collect or receive a greater or less or different compensation for such transportation of passengers or property . . .; nor shall any carrier refund or remit in any manner or by any device any portion of the rates, fares and charges so specified, nor extend to any shipper or person any privileges or facilities in the transportation of passengers or property except such as are specified in such tariffs.

124. 45 F.2d 242 (S.D.N.Y. 1930), aff'd, 55 F.2d 1053 (2d Cir. 1932).

125. Pittsburgh, C., C. \& St. L. Ry. v. Fink, 250 U.S. 577, 581 (1919); Lousiville \& N.R.R. v. Maxwell, 237 U.S. 94, 97 (1915).

126. Louisville \& N. R.R. v. Maxwell, 237 U.S. 94,97 (1915).

127. Louisville \& N. R.R. v. Central Iron \& Coal Co., 265 U.S. 59, 65 (1924); New York

Cent. \& Hudson River R.R. v. York \& Whitney Co., 256 U.S. 406, 408 (1921).

128. Louisville \& N. R.R. v. Central Iron \& Coal Co., 265 U.S. 59, 65 (1924).

129. Louisville \& N. R.R. v. Maxwell, 237 U.S. 94, 97 (1915).

130. 45 F.2d at $242-43$.

131. 46 U.S.C. $\$ 815$ (Second) (1970).

132. 46 U.S.C. $\$ 815$ (1970 \& Supp. V 1975). 
corresponding provision in the Interstate Commerce Act. ${ }^{133}$ The court stated in a footnote that "[a]ppellants reliance upon cases construing Section 10(3) of the Interstate Commerce Act . . . is misplaced. The statutory language, the legislative history, and the statutory context are quite different." "134 But an examination of the statutory language, legislative history and statutory context would indicate that the court was incorrect in this instance.

Section 10(3) of the Interstate Commerce Act prohibits the use of any device to obtain transportation at less than the regular established rates. ${ }^{135}$ The statutory language is almost identical to that found in section 16 of the Shipping Act. ${ }^{136}$ It is true that the Interstate Commerce Act contains an additional provision that specifically prohibits the acceptance of rebates by persons utilizing the transportation services of the carrier. ${ }^{137}$ But the absence of a similar provision in the Shipping Act should present no obstacle to the application of the principle that similar provisions in the two statutes should be construed in a like manner. Uniform judicial construction of the Shipping Act indicates that, albeit subject to possible limitations, a shipper may be held liable under section 16 for accepting a rebate for the purpose of obtaining transportation at a rate lower than that set forth in the applicable tariff. ${ }^{138}$ Thus, the courts have developed a body of judicial law that renders

133. 49 U.S.C. \& 10(3) (1970). See note 135 infra.

134. $316 \mathrm{~F} .2 \mathrm{~d}$ at $385 \mathrm{n} .10$. The court provided no elaboration of this conclusory statement.

135. 49 U.S.C. $\$ 10(3)(1970)$. Section 10(3) provides:

Any person. . . who shall deliver property for transportation to any common carrier ... who shall knowingly and willfully, directly, or indirectly . . . by false billing. . . or by any other device or means, whether with or without the consent or connivance of the carrier . . . obtain or attempt to obtain transportation for such property at less than the regular rates then established ... . shall be deemed guilty of fraud, which is declared to be a misdemeanor, and shail, upon conviction . . . be subject for each offense to a fine of not exceeding $\$ 5,000$ or imprisonment . . . not exceeding two years, or both, in the discretion of the court.

136. See text accompanying note 49 supra.

137. 49 U.S.C. $\$ 41(1)(1970)$. Section 41 (1) provides:

'[I]t shall be unlawful for any person . . . to offer, grant, or give, or to solicit, accept, or receive any rebate . . . in respect to the transportation of any property in interstate or foreign commerce by any common carrier. . . whereby any such property shall be any device whatever be transported at a less rate than that named in the tariffs published and filed by such carrier . . . or whereby any other advantage is given or discrimination is practiced. Every person or corporation, whether carrier or shipper, who shall, knowingly, offer, grant, or give, or solicit, accept, or receive any such rebates . . . shall be deemed guilty of a misdemeanor, and on conviction thereof shall be punished by a fine of not less than $\$ 1,000$ nor more than $\$ 20,000$.

In addition, the shipper who accepts a rebate may be fined in the amount of three times the amount of the rebate received. According to $\S 41(3)$ :

Any person .... who shall deliver property for interstate transportation to any common carrier. . . . who shall knowingly ... directly or indirectly . . . receive or accept from such common carrier any sum of money or any other valuable consideration as a rebate or offset against the regular charges for transportation of such property . . . shall in addition to any penalty provided by said sections forfeit to the United States a sum of money three times the amount of money so received or accepted and three times the value of any other consideration so received or accepted.

Id. § 41(3).

138. See, for example, the Hohenberg Brothers and Peninsular cases, discussed in notes 52 -

74 supra and accompanying text. 
section 16 of the Shipping Act an approximate equivalent of section 1(1) of the Elkins Act. ${ }^{139}$

It is well established that one of the primary purposes underlying the enactment of the Interstate Commerce Act was to provide for the uniform treatment of all users of transportation services and to eliminate discriminatory practices of all types. ${ }^{140}$ This aim, which corresponds to the primary purpose of the Shipping Act, ${ }^{141}$ has been recognized by numerous courts. ${ }^{142}$ Prior to the enactment of the Interstate Commerce Act, railroad traffic had been governed by the principles of common law which merely required that common carriers transport the property of all persons who applied and that the rates for such transportation be reasonable. Although the weight of authority favored equal charges for all persons obtaining similar services, there was some doubt under the common law as to whether carriers were required to establish uniform rates to be charged to all users for the same service. ${ }^{143}$ It was the possibility of discrimination resulting from this ambi-

139. 49 U.S.C. $\S 41$ (1970).

140. Howitt v. United States, 328 U.S. 189, 192 (1946). As the Supreme Court observed: "' 'Discriminatory rates are but one form of trade barriers.' Their effect is not only to impede established industries but to prevent the establishment of new ones, to arrest the development of a State or region, to make it difficult for an agricultural economy to evolve into an industrial one." New York v. United States, 331 U.S. 284, 308 (1947) (citing Georgia v. Pennsylvania R.R., 324 U.S. 439,450 (1945)).

In construing the statutes, the courts are instructed to consider the legislative history, and out of different possible constructions, [to] select and apply the one that best comports with the genius of our institutions and, therefore, most likely to have been the construction intended by the law-making power. Commerce, in its largest sense, must be deemed to be one of the most important subjects of legislation, and an intention to promote and facilitate it, and not to hamper or destroy it, is naturally to be attributed to Congress.

Texas \& Pac. Ry. v. ICC, 162 U.S. 197, $218-19$ (1896). Both the ICC and the courts are reminded to look to all of the pertinent circumstances and to consider the legitimate interests of the carriers as well as those of the shippers. Id. at 218. It should also be remembered that it is not the relation of the carriers to one another which is important, but their relation with those who use their transportation services. It is the patrons who are entitled to uniform treatment by the carriers. ICC v. Baitimore \& O.R.R., 225 U.S. 326, 342 (1912).

141. See note 27 supra and accompanying text.

142. See, e.g., New York v. United States, 331 U.S. 284, 296 (1947) ("' $[$ t]he principal evil at which the Interstate Commerce Act was aimed was discrimination in its various manifestations"); Union Pac. R.R. v. United States, 313 U.S. 450,463 (1941) ("there has been a welldefined and continuous purpose to eliminate preferences to shippers from our system of transportation for reasons of fairness and to avoid rate wars, detrimental to the efficiency of the carriers"); ICC v. Baltimore \& O.R.R., 145 U.S. 263, 276 (1892) ("[t]he principal objects of the Interstate Commerce Act were to secure just and reasonable charges for transportation; to prohibit unjust discriminations in the rendition of like services under similar circumstances and conditions; to prevent undue or unreasonable preferences to persons, corporations or localities; to inhibit greater compensation for a shorter than for a longer distance over the same line; and to abolish combinations for the pooling of freights"); Farley Terminal Co. v. Atchison, T. \& S.F. Ry., 522 F.2d 1095, 1097 (9th Cir.), cert. denied, 423 U.S. 996 (1975) ("'ii]t is well recognized that the principal congressional purpose in enacting the Interstate Commerce Act was to obtain a uniformity of rates and an end to discriminatory practices").

143. ICC v. Baltimore \& O. R.R., 145 U.S. 263, 275 (1892). 
guity that the Interstate Commerce Act was designed to eliminate. With regard to the specific issue of rebates, one court has observed that the congressional intent behind the Interstate Commerce Act's tariff provisions was specifically to prevent rebates and to require that all shipments be made at the same rate. ${ }^{144} \mathrm{~A}$ similar purpose is perceived as underlying the enactment of the Shipping Act. ${ }^{145}$

In giving effect to the perceived intent behind the statute, courts have applied a policy of strict enforcement to the requirement under section 6(7) of the Interstate Commerce Act that no rate differing from the filed tariff shall be charged by a carrier. ${ }^{146}$ In addition, patrons have been required to pay the full tariff charge regardless of initial misquotations or miscalculations of charges by the carrier. While the possibility of harsh results in individual cases is recognized, it is believed that the strict construction is

144. Atchison, T. \& S.F. Ry. v. Midland Cooperatives, Inc., 306 F. Supp. 723, 725 (W.D. Okla. 1969). That court would allow the parties to stipulate as to who should pay the charge, so long as the same rate was charged to all. Id.

There is ample support for the notion that the major purpose of the Elkins Act, 49 U.S.C. $\$$ § 41-67 (1970 \& Supp. V 1975), is to eliminate rebates and other such concessions and discriminations in order to allow all persons to obtain transportation for their property on an equal basis. Union Pac. R.R. v. United States, 313 U.S. 450, 461 (1941). However, it is not possible to rely on decisions construing the Elkins Act in order to determine the applicability of $\S 16$ of the Shipping Act to various categories of rebates because the shipping Act contains only those provisions of the Interstate Commerce Act that deal specifically with the question of rebates. See note 137 supra and accompanying text. Under $\$ 1$ of the Elkins Act, 49 U.S.C. \$41 (1970), the substance of the offense is the solicitation or receipt of the concession, rather than the device by which it is effected. United States v. Satuloff Bros., 79 F.2d 846, 849 (2d Cir. 1935). Thus, it is quite clear that the concession may be either secret or open, fraudulent or honest. Id. at 849-50 (citing Armour Packing Co. v. United States, 153 F. 1, 16 (1907), aff'd, 209 U.S. 56 (1908)). But the substance of the shipper's offense under $\S 10(3)$ of the Interstate Commerce Act is the fraudulent device. 79 F.2d at 849 . Thus, it will be necessary to rely upon judicial opinions interpreting that provision in order to determine whether an element of concealment or intent is required for a violation of $\$ 16$ of the Shipping Act to exist.

145. See notes 27-36 supra and accompanying text.

146. Southern Pac. Co. v. Miller Abattoir Co., 454 F.2d 357, 359 (3d Cir. 1972). Because the carrier is said to have a duty as well as a right to enforce payment of the full tariff charges, contracts to provide transportation for less are rendered void and will not prevent the carrier from recovering the full amount. $I d$, at 359 . Thus, the parties are not free to enter into special contracts or agreements in order to evade the uniformity of treatment of all shippers required under the Interstate Commerce Act. Cooper v. Chicago, R.I. \& Pac. R.R., 217 F.2d 683, 685 (8th Cir. 1954). According to the Supreme Court, the congressional intent to prevent discrimination may not be frustrated by contracts, even in those situations where the contract was executed prior to the enactment of the Interstate Commerce Act. United States v. Baltimore \& O.R.R., 333 U.S. 169, 175 (1948). Therefore, in any case in which a charge differing from the published tariff rate is collected, either the carrier or the shipper will have a cause of action to collect the difference between the amount and the lawful rate. Atchison, T. \& S. F. R.R. v. Judson Freight Forwarding Co., 49 F. Supp. 789, 795 (S.D. Cal. 1943), aff'd sub nom. National Carloading Corp. v. Atchison, T. \& S.F. Ry.,150 F.2d 210 (1945). A similar policy of enforcement under the Shipping Act is found with regard to the requirement that the full tariff rate be charged in every case. See notes 33-35 supra and accompanying text. 
necessary if the desired goals of uniform treatment of shippers and prevention of discrimination and favoritism by carriers are to be achieved. ${ }^{147}$ The question of whether a rebate is voluntary or involuntary is considered irrelevant. Both are seen to be prohibited by the Interstate Commerce Act. ${ }^{148}$ Once a tariff, rate or charge has been duly established in accordance with the Act, it becomes the legal rate and binds both the carrier and the shipper with the force of law. ${ }^{149}$ All persons are charged with notice of the legal tariff rates. ${ }^{150}$ Consequently, the shipper's knowledge of the lawful rate is presumed. ${ }^{151}$ This construction has been applied both to section 6 , which prohibits a carrier from deviating from the published rate, ${ }^{152}$ and to section 10(3), under which shippers are forbidden to obtain transportation for less than the legally established rates. ${ }^{153}$ To determine whether there has been a violation courts will look only to the results, not to the intent of the parties. "Any and all means to accomplish the prohibited end are banned. . . . In fact favoritism which destroys equality between shippers, however brought about, is not tolerated." 154

There are statutory exceptions to the application of this strict liability, but they are based on the nature of the rebate rather than the state of mind of the parties. Only those discriminations or preferences that are unjust or unreasonable are prohibited. The Interstate Commerce Act "was not intended to ignore the principle that one can sell at wholesale cheaper than at retail." 155 The payment of damages by a carrier to a shipper has also been held not to constitute an illegal rebate under the Interstate Commerce Act. An offense is committed only in those situations involving an overpayment of damages. ${ }^{156}$ Similarly, no violation exists if the carrier reimburses the

147. Southern Pac. Co. v. Miller Abattoir Co., 454 F.2d 357, 359-60 (3d Cir. 1972).

148. Baldwin v. Scott County Milling Co., 307 U.S. 478, 485 (1939).

149. Farley Terminal Co. v. Atchison, T. \& S. F. Ry., 522 F.2d 1095, 1098 (9th Cir.), cert. denied, 423 U.S. 996 (1975).

150. St. Louis-S.F. Ry. v. Miller Floors, Inc., 293 F. Supp. 869, 870 (D. Okla. 1968).

151. Farley Terminal Co. v. Atchison, T. \& S. F. Ry., 522 F.2d 1095, 1099 (9th Cir.), cert. denied, 423 U.S. 996 (1975).

152. Lowden v. Simonds-Shields-Lonsdale Grain Co., 306 U.S. 516, 520 (1939). See note 123 supra.

153. Baldwin v. Scott County Milling Co., 307 U.S. 478, 484-85 (1939). See note 135 supra.

154. Union Pac. R.R. v. United States, 313 U.S. 450, 462 (1941).

155. ICC v. Baltimore \& O.R.R., 145 U.S. 263, 276 (1892).

A similar concept is recognized under the Shipping Act. The FMC is required to allow the use of dual rate contracts that are to be made available to all shippers on equal terms and conditions whereby lower rates are granted to a shipper who agrees to give all or any fixed portion of his business to a particular carrier or conference of carriers. 46 U.S.C. $\$ 813 a$ (1970). However, the FMC need not approve such contracts if they are found to be detrimental to the commerce of the United States, contrary to the public interest, or unjustly discriminatory between shippers or between United States exporters and their foreign competitors. Id.

156. Southern Pac. Co. v. Miller Abattoir Co., 454 F.2d 357, 360-61 (3d Cir. 1972). In the opinion of the court, the mere fact that an unscrupulous railroad might attempt to evade the laws forbidding rebates through the submission of false claims for damages was not sufficient 
shipper for the performance of services which the carrier was contractually obligated to perform. ${ }^{157}$

The requirement stated in Peninsular that an act of attempted concealment be present in order for a rebate to be considered a violation of section 16 of the Shipping Act, ${ }^{158}$ does not resemble these exceptions to the rule of strict liability. In the examples above, the rebates were found not to be discriminatory because they were lawfully accessible to all shippers on an equal basis. The concealment requirement of Peninsular, on the other hand, does not address the uniform availability of the rebate, but looks merely to the question of whether the fact of the rebate was ascertainable by the recipient's competitors. However, the mere fact that competing shippers may be aware of the carrier's rebating procedure with respect to a particular shipper may not be sufficient to insure uniform treatment. The desired uniformity of treatment for shippers is obstructed in every situation where one shipper obtains transportation at a lesser rate than the tariff filed with the FMC and charged to his competitors. Thus, uniformity will be achieved only if a construction imposing strict liability for the receipt of a rebate is given to section 16 of the Shipping Act.

\section{CONCLUSION}

On the basis of an examination of the legislative intent underlying the enactment of the Shipping Act, a reading of the statutory scheme in its entirety and a comparison with analogous provisions under the Interstate Commerce Act, it seems quite clear that any ambiguity inherent in section 16 of the Shipping Act should be resolved in favor of an extension of liability to shippers receiving illegal rebates. Not only is this conclusion supported by logic, but it represents the solution favored by principles of equity. The granting of a rebate by a common carrier is specifically prohibited by law, and consequently, no carrier will be willing to risk incurring the civil penalty which the offense carries without some expectation of profit. Two parties-a shipper and a carrier-are necessary to the commission of the offense. It seems highly unlikely that a carrier would violate the statute in the absence of some sort of encouragement by a shipper. Thus, the most logical way to obtain the desired uniformity of treatment for shippers and to facilitate enforcement of the statute's anti-rebate provisions would be to remove any incentive for the shipper to request rebates. As one court observed:

to require the denial of damage awards to those customers presenting legitimate complaints based upon a breach of duty by the railroad. Id. at 361 .

157. Hanna Furnace Corp. v. United States, 53 F. Supp. 341, 343 (W.D.N.Y. 1943), aff'd, 323 U.S. 667 (1944).

158. 208 F. Supp. at 958-59. See notes 61-74 supra and accompanying text. 
The power in the United States and in the Commission to enforce the substantive provisions of the Act must carry with it the power to make such enforcement effective. Here, enforcement can be made effective only if relief is granted against the noncarrier defendants who are causing the carriers to violate the act. ${ }^{159}$

It appears that the prohibition against the use of rebating procedures will become effective only when shippers as well as carriers are subjected to liability for engaging in such activity. Congress, the FMC and the courts all possess the authority to resolve the ambiguity in this manner.

159. United States v. City of Jackson, 318 F.2d 1, 9 (5th Cir. 1963) (relating to charges of race discrimination). 